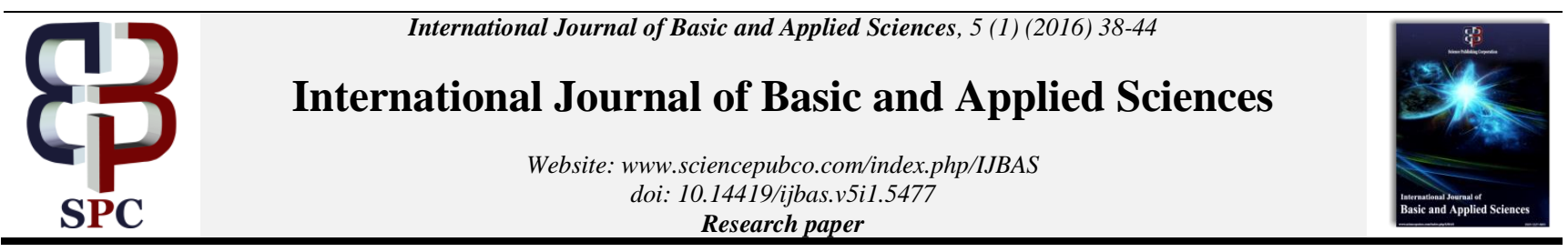

\title{
Effects of roadside dust pollution on fruit trees of miyyaghundi (Quetta) and ghanjdori (mastung), Pakistan
}

\author{
Shehnaz Sher Ahmed ${ }^{1 *}$, Rukhsana Jabeen ${ }^{2}$ Saima Johar $^{2}$, Mahjabeen Hameed ${ }^{2}$ And Shazia Irfan ${ }^{2}$ \\ ${ }^{1}$ Department of Botany, Sardar Bahadur Khan Women's University Quetta, Pakistan \\ ${ }^{2}$ Department of Botany, SBK Women's University Quetta, Pakistan \\ *Corresponding author E-mail: ajwabaloch56@gmail.com
}

\begin{abstract}
The research was conducted to evaluate the effects of road side dust pollution on fruit trees of Miyyaghundi (Quetta) and Ghanjdori (Mastung), Pakistan. The data were collected from the two orchards near the road where the road construction was in process. The effect of road side dust was observed on the leaves of trees growing at the edges of orchards as compare to those trees growing in the center of orchards. The highest percentage of dust was observed on the leaves of Pyrus malus L. (apple) which was (1.05 g) grown at the edges of an orchard compared to those leaves growing in the center of an orchard. The lowest dust $(0.08 \mathrm{~g})$ was observed on the leaves of Prunus domestica L. (plum) that were away from the road. Closure of stomata was observed highly affecting the trees grown at the edges of orchards compared to the central ones. The highest mean for closed stomata was (419.3) recorded in P. malus, grown at the edges of an orchard and the lowest mean (75) was recorded in P. domestica. The fruit production was also observed, the highest mean was recorded in Apple (pyrus malus L.) before road construction in central trees of Miyyaghundi which was ( $200 \mathrm{~kg})$. The lowest mean for fruit production was recorded in Apple (pyrus malus L.) trees grown at the edges of an orchard that was (15 kg).
\end{abstract}

Keywords: Dust Pollution; Closure of Stomata; Accumulated Dust on Leaves; Effect on Fruit Production.

\section{Introduction}

Pakistan is a country where all fruits of all seasons and topography are grown. Such as Apples, Plums, Apricots, Peaches, Bananas, Dates, Mangoes, Cherry, Melon and Water melon etc. These citrus fruits are well-liked inland and abroad. Pakistan has gifted from the fertile soil, suitable environment and good climatic conditions. Pakistan is one of those countries on planet where all four seasons occurs. That's why it produces ample fruits and vegetation. Pakistan exports these fruits to about 60 countries.

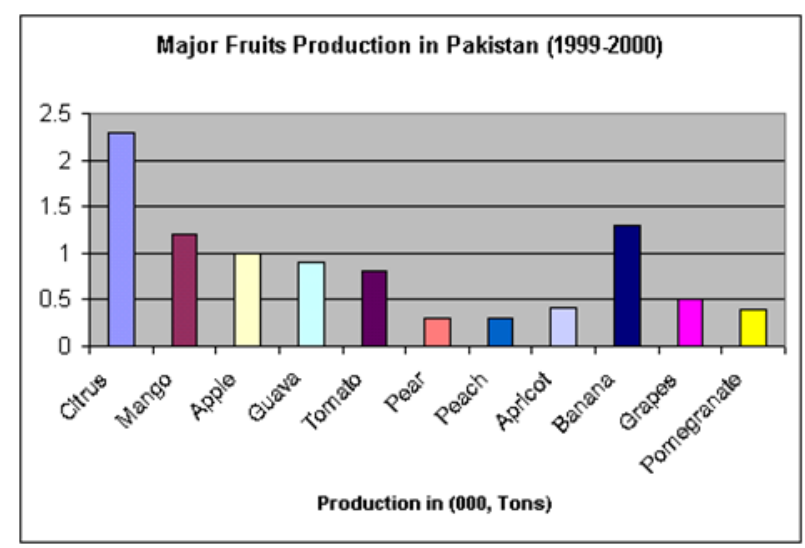

Fig. 1: Fruit Production in Pakistan. population. This province lies between latitude $24 \varnothing 55$ and $32^{\circ} .04$ North and longitude $60^{\circ} .45$ and $70^{\circ} .17$ East. The population of this province has increased at an average annual growth rate of $2.42 \%$ as compared to the national average $2.61 \%$. There are 29 districts of Balochistan [53].

Balochistan is known as fruit basket of Pakistan. Balochistan is gifted with distinctive environment where different verities of fruits are produced. The province is also known as fruit garden of Pakistan producing $90 \%$ of grapes, Cherry and Almonds, $60 \%$ of peach, pomegranate, apricot, $34 \%$ of apple and $70 \%$ of date. Growing fruit trees in Balochistan are more than an area of 1, 49, 726 hectares which yields about 0.9 million tons annually [10]. Grapes are delicious fruits grown in Quetta, (Pishin, Kalat, Zhob, Loralai and Mastung districts). These areas are well-known for production of varieties of grape such as Kishmishi and Sundarkhani.The Apricots, Plums and Peaches are grown in uplands of Balochistan. This province contains large amount of coal, gas, gold and different minerals [66].

Balochistan is the province of Pakistan extends over a large area (347,190 sq. km. forming 43.6\% of the total area of Pakistan. Balochistan is the largest province of Pakistan but has the smallest 


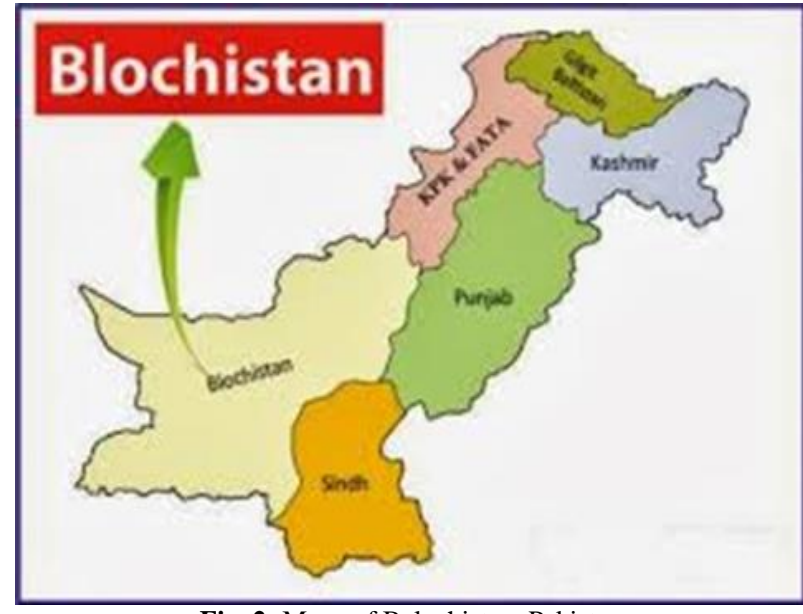

Fig. 2: Mape of Balochistan, Pakistan

Apple (Pyrus malus) belongs to family Rosaceae. About 50006000 varieties of apple are described [10]. Apple contains large amount of vitamin A, vitamin B and vitamin C. $80 \%$ of apple produced in Pakistan is contributed by Balochistan and is mainly produced in Kalat, Killa Saifullah, Loralai, Mastung, Pishin, Quetta and Ziarat districts. The area about this fruit has openly increased more than five times during the period from 1980-81 to 1996-97 [3]. Peach (Prunus persica L.) is important and economic fruit tree of Balochistan, cultivated in the area about of 60.22 hectare and produce 30.31 tons [66].Plum (Prunus domestica) is far and wide cultivated. These may have erect growing trees, which depends on the variety. The leaves have different shapes, usually egg-shaped. The fruits are oval or round shaped which having smoothed and thin skin. The fleshy tissue may be purple, blue, red, green or yellow all are also depending on the variety. More than 2,000 varieties of Plums are available. These trees bear fruit after three years planting. Plums may be used freshly, preserved in jams, dried as prunes, and juiced [3].

Apricot (Prunus armeniaca) produced in Northern areas of Pakistan. In Pakistan about 170680 tons fruits produce per year. The fruit production in Balochistan is the major source of income. In Balochistan P. armaniaca is produced in Mastung, Kalat, Ziyarat, Zhob and Pashine [40].

Mastung is a beautiful city and rich in fruit orchards and is a mountainous area. The mountains of Mastung contain broad range of medicinal plants, which are used for various diseases by local people. The mountains of Mastung are namely Chiltan, Aamach etc. The population of Mastung was estimated over 180,349 in 2005. In Mastung $99 \%$ of people is Muslim by faith and Baloch by race. The local language of this district is brahvi and dehwari (a broken shape of Persian).

A few years ago the Mastung city was called the city of Karez water system. There were lots of Karezes here in this city almost 360 in number. The famous were 'Qadi' Karez, 'Noth' Karez and 'sour' karez. But with the passage of time almost all these Karezes were dried out except one or two. Now the rigs/turbines through electricity power take place for irrigating the orchards and other cultivated lands for agri business. The economy of Mastung depends upon agriculture. This city is famous in providing of fruits in province. The famous fruits of this city are apple, plum, peach, apricot, grapes and pomegranates. In 2005 few projects of road construction were started in this city. The main project was construction of national highway (from Quetta to Karachi). The period of completion of work was 2 years only but still this construction is in running stages. Due to this prolonged construction, the fruit orchards near the projects are being destroyed by dust of vehicles and pollution induces by heavy machineries and nontreated vehicle traffic. This has been caused an increase in poverty and a great loss in the economy of the province. The most effected fruits are apples, plums, peaches, apricots, grapes and few others. The substances, which cause pollution, are called pollutants. Pollution is that any substance which released purposely or accidently by human beings into the environment that may have undesirable effect on atmosphere or water although; Soil and vegetation in Industrial areas showed variations due to expulsion of different types of pollutants [28]. Plants can uptake and accrue pollutants through their leaf surfaces and roots [57]. Leaves can act as biological and natural absorbers of pollutants [20]. In the industrial areas the air pollution has become a major threat to the survival of plants [23]. The plants are much more sensitive in comparison to other organism that is the contact on the plant community has also been studied wide-reaching in terms of plant-environmental interactions [5]. But most air pollutants reduce photosynthesis directly or indirectly by causing loss of photosynthetic tissues and also affects the stomatal opening [48]. Many gases, particulates, aerosols and airborne pollutants were trapped and absorbed by important sinks such as Plant species, particularly trees and shrubs [17].

In the assimilation and accumulation of pollutants the road side play significant role and act as capable interceptors of airborne pollutants. Studies showed that the plants develop different morphological, physiological and anatomical changes under polluted conditions [25]. Heavy metals are responsible for reducing the growth of plants [5].In urban centers of the world motor vehicles have been closely identified with increasing in air pollution levels [34].These are responsible for 60 to $70 \%$ of the population found in an urban environment [62]. The productivity and concentration of annual non-leguminous crops were decreased by cement dust [56].The studies were undertaken due to changes caused by urban air pollution on number and size of stomata and epidermal cells in the leaves of road side tree species, such as pongamia pinnata (L) Merr. The Portland cement consist of clinker, volcanic rock, and hydrate gypsum are manufactured by untreated substances which are enrich in $\mathrm{Al}, \mathrm{Ca}, \mathrm{Si}, \mathrm{Fe}, \mathrm{Mg}$ [63], these also contain $\mathrm{Mn}, \mathrm{Cu}$, $\mathrm{Zn}, \mathrm{Ni}, \mathrm{Pb}, \mathrm{Co}, \mathrm{Cr}, \mathrm{Cd}$ and other trace elements. Cement dust caused alkalization of soil and the alkaline dust deposited on trees which distorted the accessibility of several nutrients, causing serious deviations in the mineral composition of trees [36].

Road side dust may also contain considerable concentrations of inorganic elements and may generate alkaline dusts [15]. It has been established that Vehicle derived particulates are particularly dangerous to human health [52].

\section{Materials and methods}

The data was collected from two orchards of Mastung and Quetta in 2013. One orchard was selected from the orchards of Miyyanghundi-site 1 (Quetta), and the other was selected from the orchards of Ghanjdori-site 2 (Mastung). The leaves were plugged randomly from the center and edges of the orchards. The data was brought in the labeled file envelops to the laboratory for further investigation. In present study four roadside leaves of fruit trees i e. Pyrus malus L. (apple), Prunus armeniaca L. (apricot), Prunus persica L. (peach) and Prunus domestica L. (plum) were selected from Miyyaghundi and Ghanjdori.

To evaluate the dust effect on stomata the leaf surface characteristics were studied under light microscope. One centimeter square dorsal side of leaf surface (Fig. 1A) was painted with transparent varnish (Fig. 1B) on lower and upper surface of leaves. The leaves left in open air for 10 minutes to dry transparent varnish. The dried transparent varnish carefully removed from the leaf surfaces and observed leaf impressions under the light microscope. Microphotographs were taken to observe opening and closing conditions of stomata [53]. 


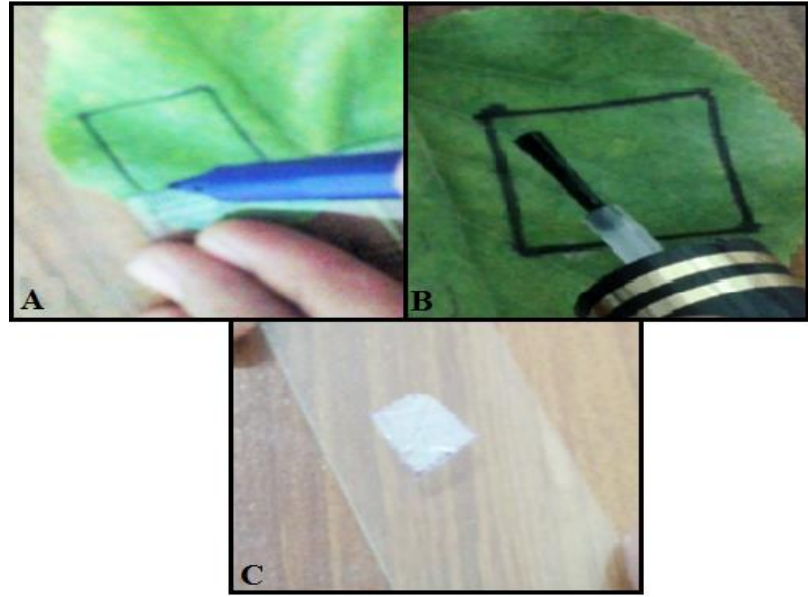

Fig. 3: Preparation of Sample to Observe Condition of Stomata. A: Measurement of $1 \mathrm{Cm}$ Square of Leaf Area, B: Fixing of Stomata Applying Transparent Varnish. C: Pealing Off Transparent Varnish.

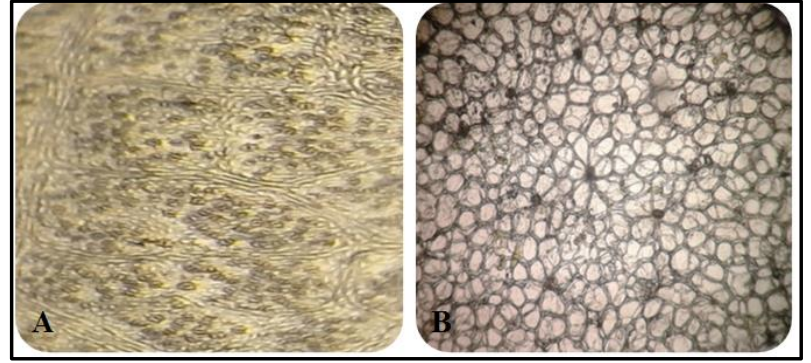

Fig. 4: Conditions of Stomata under Microscope. A: Impression of Closed Stomata of Leaves Collected from the Trees Grown in the Edges of the Orchard. B: Impression of Opened Stomata of Leaves Collected from the Trees Grown at the Center of the Orchard.

To observe the effect of dust on leaf surfaces the accumulated dust was also measured. For this purpose $20 \mathrm{~g}$ of leaves of each tree was soaked in $250 \mathrm{ml}$ of distilled water. The leaves were shaken with lass starrier. The water was filtered through pre-weighted filter papers on digital balance. After filtration the filter papers were dried at $80^{\circ} \mathrm{C}$ in an oven for $10 \mathrm{~min}$ and reweighed three times to obtain constant weight of accumulated dust particles in triplicates.

\section{Results}

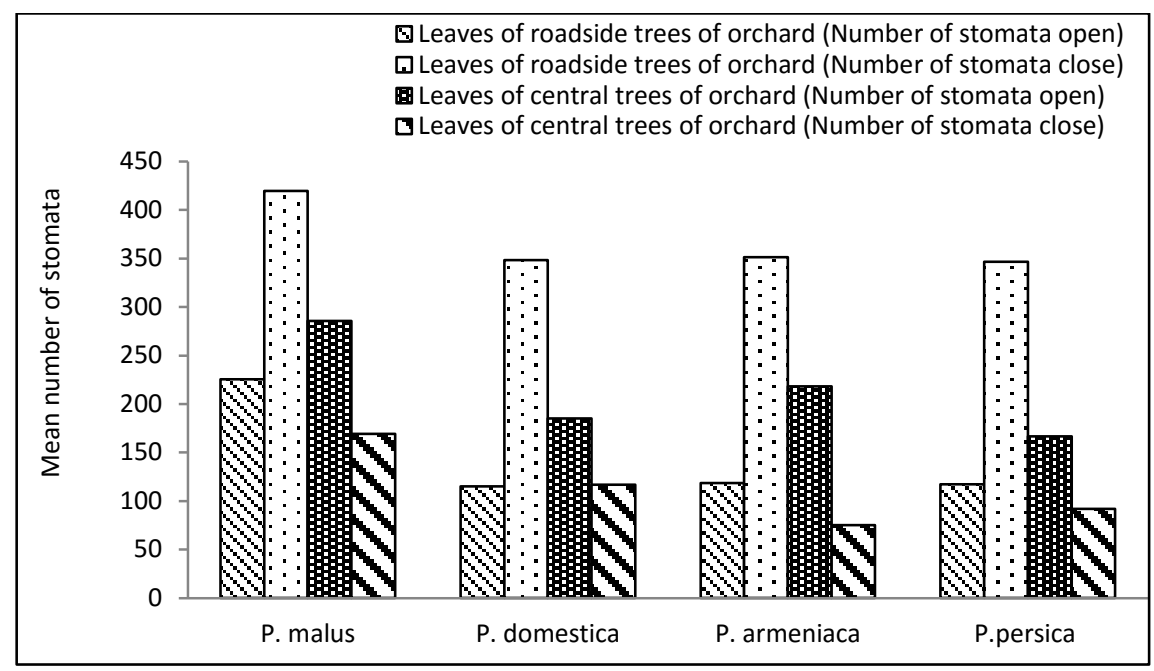

Fig. 5: Showing the comparison of mean values of open and closed stomata from roadside and central trees grown in orchard at Miyyanghundi, Quetta (Site 1).

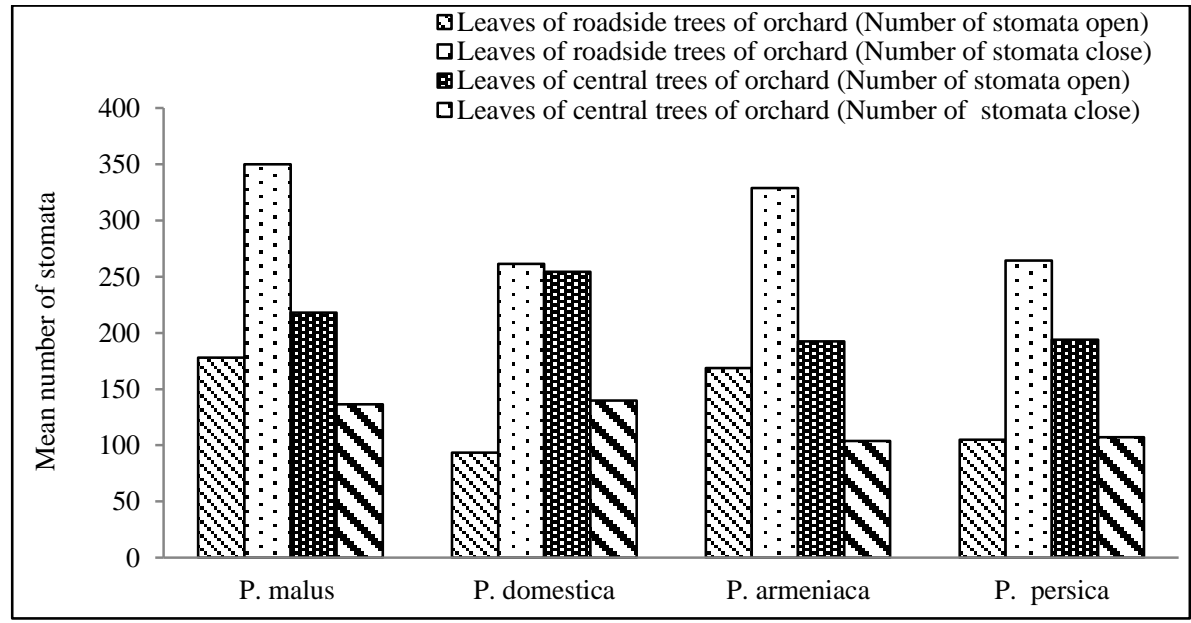

Fig. 6: Showing the comparison of mean values of open and closed stomata from roadside and central trees grown in orchard at Ghanjdori, Mastung (Site 2). 


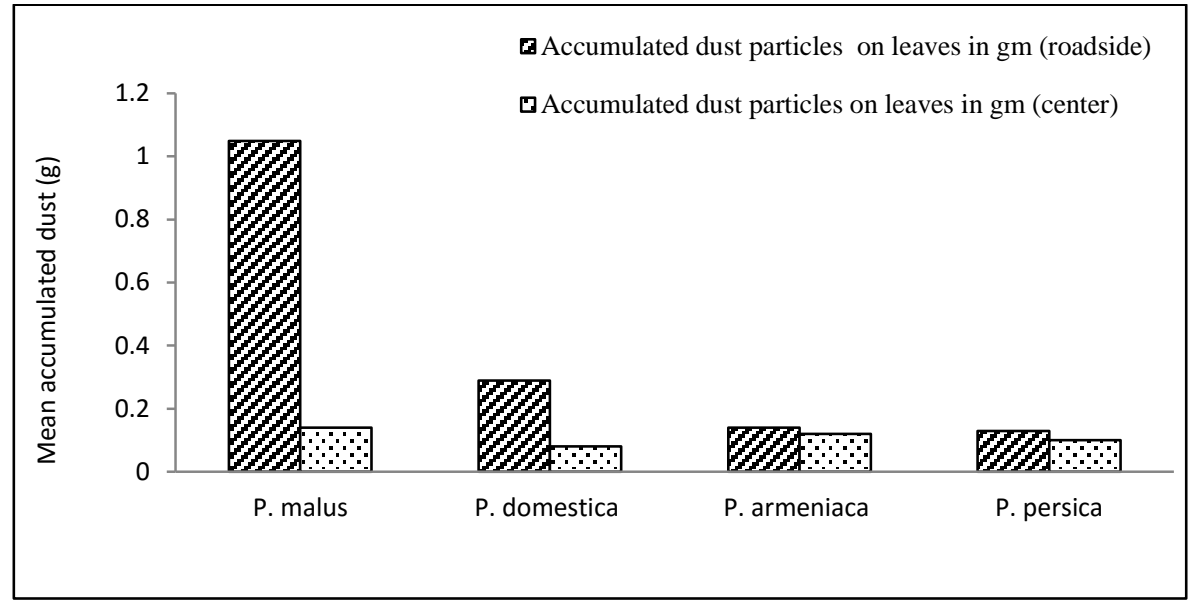

Fig. 7: Mean values showing the accumulated dust on leaf surfaces of trees grown In Orchard at Miyyanghundi, Quetta (Site1).

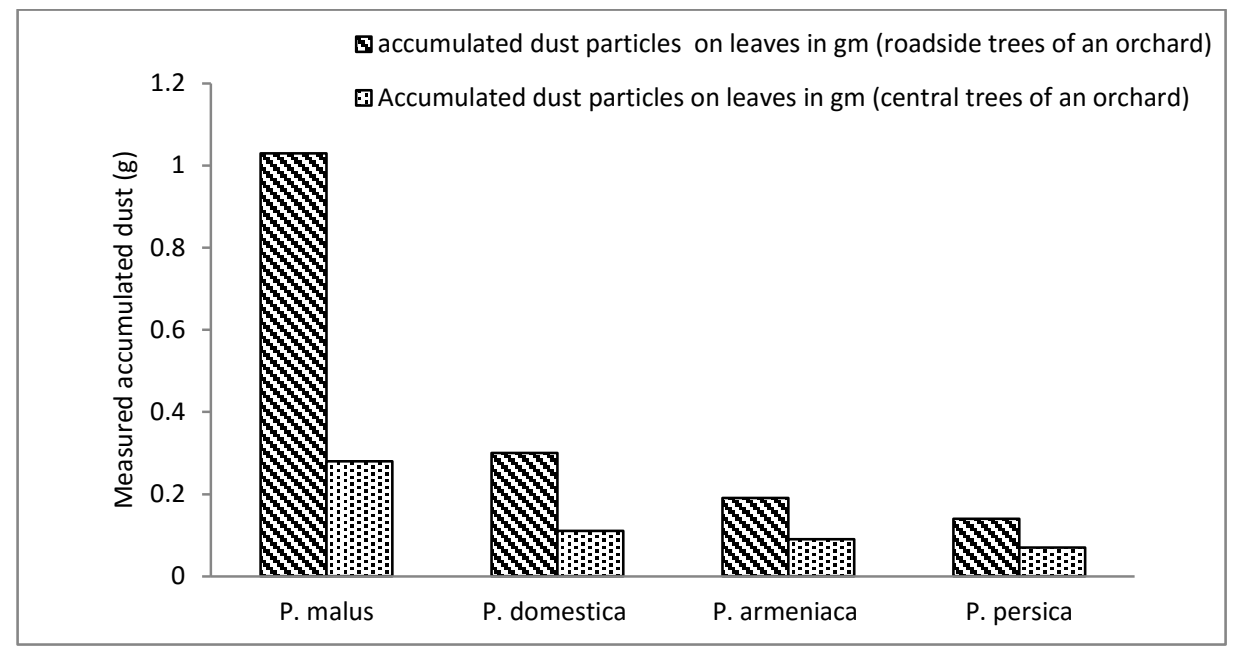

Fig. 8: Mean values showing the accumulated dust on leaf surfaces of trees grown In Orchard at Ghanjdori, Mastung (Site 2).

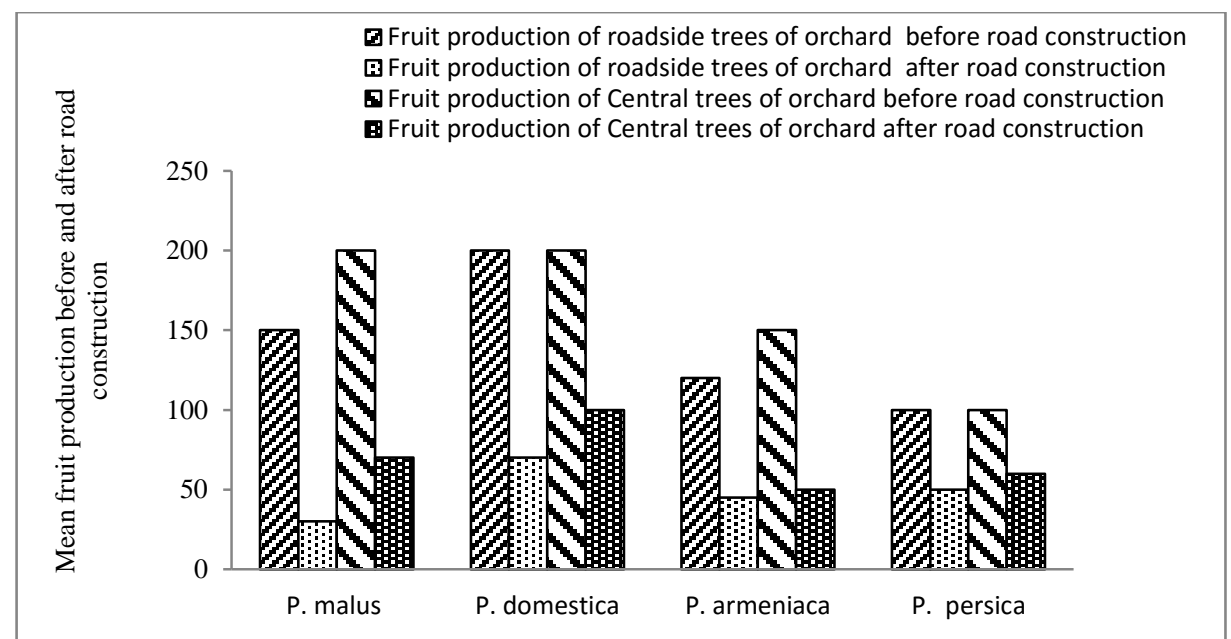

Fig. 9: Mean Values of Fruit Production before and after Road Construction at Miyyaghundi, Quetta (Site 1) 


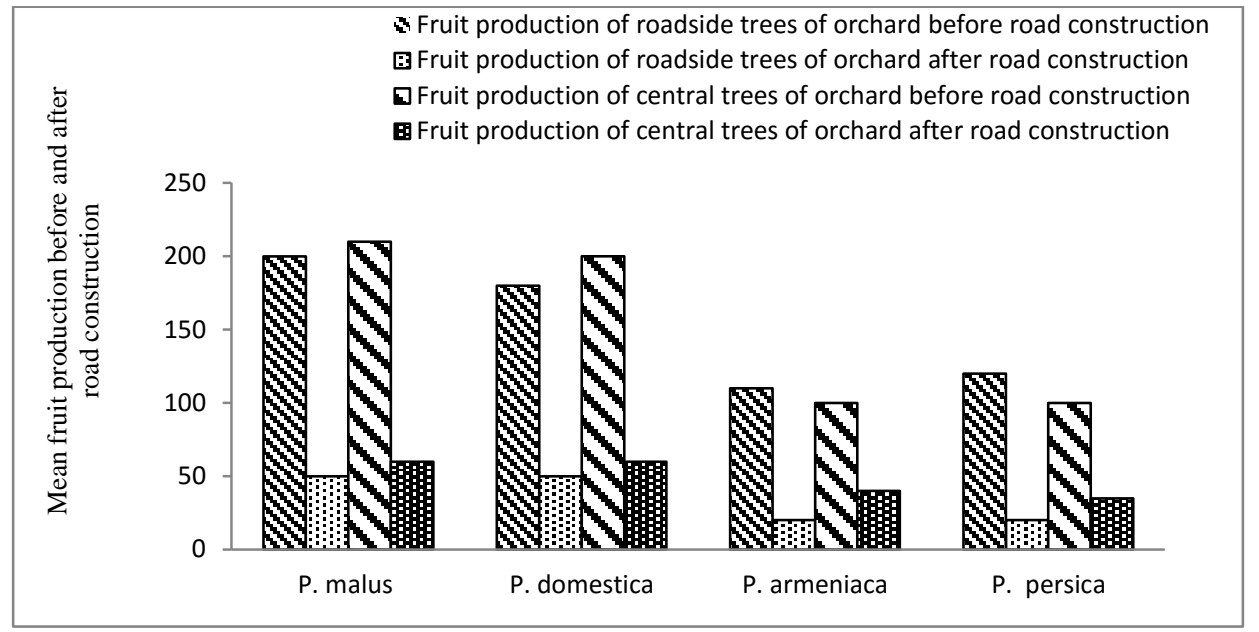

Fig. 10: Mean Values of Fruit Production before and after Road Construction at Ghanjdori, Mastung (Site 2).

\section{Discussion}

One main cause of air pollution in Mastung is roadside dust due to the road construction. Due to these prolonged constructions, the fruit orchards near the projects are being destroyed by dust of vehicles and pollution induces by heavy machineries and nontreated vehicle traffic. This has been caused an increase in poverty and a great loss in the economy of the country. The most effected fruits are apples, plums, peaches, apricots, grapes and few others also. The dust particles which are producing due to the road construction are highly affecting the roadside orchards in which Apple, Plum, Peach, and Apricots are included. In the present study the data was collected from two orchards near the roads where road construction was in process. For the investigation the leaves of Apple, Plum, Apricot and Peaches were collected. Because the leaves are the parts of the plants that accumulate any particles that are may be dust particles, heavy metals etc present in air.

Air pollution is a major problem in many countries [33]. The vegetation is badly affected by air pollution and is observed that all plants are act as dust filters in polluted areas [53]. The dust on the leave surfaces of these trees were observed the highest rate of dust which was $(1.05 \mathrm{gm})$ in the leaves of pyrus malus L. from site 1 (Miyyaghundi) and the lowest result was observed in the leaves of Prunus domestica L. that were away from the roads and the leaves contain $(0.08 \mathrm{gm})$ dust. Many scientists observed that air pollution causes the changes in leaf surfaces and characteristics [64]. The roadside pollution decreases the rate and growth of plants. The cement dust is harmful for human beings and also the plants and other living organisms by the harmful chemicals such as chromium and copper [46]. The Urban air pollution is the contribution of diesel and gasoline fuels in cars, buses and other transportation [2].

The dust particles which are producing due to the road construction are highly affecting the roadside orchards in which Apple, Plum, Peach, Apricots and Grapes are included. The results of present study were showed that the trees at the edges of orchards highly affected then the middle ones. Because the trees of edges were near to the roads where they were directly in contact to the vacuolar traffic, and directly face the dust pollution of road construction.

The stomata are pore like openings which are found in underside of leaves singularly known as stoma. There are two guard cells of each of stomata which control the opening and closing of stomata. These stomata allow the Carbon dioxide; Oxygen and water vapors circulate into and out of the leaf by opening and closing. The process of transpiration and photosynthesis in plants occurs due to stomatal opening and closing [67]. In the absence of stomata or when the stomata are affected in that case the supply of carbon dioxide and oxygen for transpiration and photosynthesis are highly affected which cause dehydration in plants therefore it was observed that the opening and closing of stomatal aperture is very important for the growth of plants [11].

In the present study the opening and closing of stomata of leaves of the trees near to the roads were observed which were highly affected due to the dust of road construction. In another study the stomata of leaves were analyzed and it was observed that the air pollutants such as $\mathrm{SOz}$, Ozone and fluorides on stomata is much less important because these pollutants cause closing of stomata and the opening and closing of stomata is important for gaseous exchange in plants [45]. In the present study it was also observed that the dust of vehicles and road construction causes closing of stomata because the dust particles are the polluted factors which have phytotoxic effects on plants. As a result the number of metabolic processes such as (photosynthesis, transpiration, respiration) in plants becomes highly affected [35].

In the present study the leaves of polluted and unpolluted sites were observed. The leaves of tress that were near to the roads were highly affected as compare to the leaves of that trees that were away from the roads. The highest result of close stomata that were (419.3) observed in the trees of pyrus malus L. which were near to the roads and directly facing the dust of road construction and vehicles. Same results were observed in size and number of stomata and epidermal cells from polluted sites as compared to the uncontaminated sites [63]. The highest value of open stomata that were (285.3) observed in the trees of Prunus domestica L. which were away from the roads and not that much dust as compare to those trees that were near to the roads. The air pollution affects plants directly by leaves and indirectly by soil [29]. The dust due to cement construction was observed on plumule and radicles of most trees which were affected due to cement dust even at $200 \mathrm{~g}$ dust $/ \mathrm{kg}$ soil [56]. The air pollution affects the plants their flowering and fruit maturation and appearance of new leaves. Even the senescence and fruit production of trees are also disturbed due to air pollution [8]

Currently the researches had determined the mechanism of stomatal fluctuation induced by environmental pressure [27]. The deposition of dust affect many physiological processes on plants including photosynthesis, stomatal functioning and productivity by covering and plugging stomata, shading and removing cuticular wax [39]. Chlorophyll fluorescence, an indication of the fate of excitation energy in the photosynthetic apparatus, has been used as an early, in vivo, response of plant response toward different stresses [21]. It was found that phytotoxic chemicals from pollutants affect a number of metabolic functions such as transpiration, respiration, photosynthesis [35]. Stomatal opening is changed with plant exposure to pollutants [54]. The symptoms of pollution impact upon trees are investigated in physiological, biochemical, and morphological aspects [41]. From many studies it was found that the dust affects the photosynthesis and gas exchange and also effect the function of stomata, increase leaf temperature [15], and transpiration [7] decrease photosynthesis [12] and enhance the uptake of gaseous pollutants [13]. There were many factors found 
involved in opening and closing of stomata [24]. There were different factors which interact in a complex manner [1].

\section{Conclusion}

By this study it was concluded that the roadside dust highly affects the fruit trees. The leaves of these trees were highly affected due to the dust of road construction. The dust on the leave surfaces of these trees were observed the highest rate of dust which was (1.05 $\mathrm{gm})$ in the leaves of Pyrus malus L. and the lowest result was observed in the leaves of Prunus domestica L. that were away from the roads and the leaves contain $(0.08 \mathrm{gm})$ dust It was also concluded that the stomata of leaves of these trees were highly affected due to this the rate of chlorophyll, the growth of these trees and the fruit production also decreases The highest result of close stomata that were (419.3) observed in the trees of Pyrus malus L. which were near to the roads and directly facing the dust of road construction and vehicles

\section{References}

[1] Aggarwal, P. 2000. The effect of auto-exhaust pollution on leaf surface of Cassia siamea (L.), a road side tree. Acta Ecologica 22:101106.

[2] Anonymous.1999. Agricultural Statistics of Pakistan. 1998-99. Government of Pakistan, Ministry of Food, Agriculture and Livestock, Food, Agriculture and Livestock Division (Economic Wing), Islamabad.

[3] Anonymous. 2004. U.S. EPA, Air Quality Criteria for Particulate Matter, US Environmental Protection Agency.

[4] Anwar, B. 2011. Balochistan: Improving fruit production. Daily Dawn Newspaper, (23 May).

[5] Atiq-Ur-Rehman,S., and M.Z. Iqbal.2008. Level of heavy metals on the Foliage of naturally growing plants collected from Korangi and Landhi industrial areas of Karachi city < Pakistan. Pakistan Journal of Botany, 40(2), 785-789.

[6] Auto exhaust pollution. Journal of Environmental Biology 21 (1): $15-21$.

[7] Bernatzky, A.1978. Tree Ecology and Preservation, Development in Agricultural and management Forest Ecology, 2 Elsevier Scientific Publishing Co.New York.

[8] Bhatti, G.H and M.Z. Iqbal.1988. Investigation into the effect of automobile exhausts on the phenology, periodicity and productivity of some roadside trees. Acta Sac. Bot. Polon, 57:395-399 http://dx.doi.org/10.5586/asbp.1988.038.

[9] Casselles, J.1998. Levels of lead and other metals in Citrus alongside a motor road. Water, Air, Soil Pollute, 105:593 - 602 http://dx.doi.org/10.1023/A:1004937224850.

[10] Chaudary, M.I.1994. Fruit crops book of Horticulture, Sponsored by United states Agency for international Deveploment Mission to Pakistan. Published by the National Book Foundation Islamabad.

[11] Cowan, L. R. 1982. Regulation of water use in relation to carbon gain in higher plants. In "Encyclopedia of Plant Physiology" 0.L Lange and J. D.Bewley, eds, 12, 535-562. http://dx.doi.org/10.1007/978-3-642-68150-9_18.

[12] Dineva, S.2004. Comparative studies of the leaf morphology and structure of white ash Fraxinus americana L. and London plane tree Platanus acerifolia willd. Growing in polluted area. Dendrobiology. 52, 3-8.

[13] Dineva, S.2006. Development of leaf blades of Acer platanoides in industrially contaminated environment. Dendrobiology 55, 25-32.

[14] Dogan, Y., N. DURKAN, S. BASLAR. 2007. Trace element pollution biomonitoring using the bark of Pinus brutia (Turkish red pine) in the Western Anatolian part of Turkey. - Trace Elements and Electrolytes, 24, 146-150. http://dx.doi.org/10.5414/TEP24146.

[15] Farmer, A.M.1993. The effects of dust on vegetation - a review. Environ. Pollut. 79:63-75 http://dx.doi.org/10.1016/02697491(93)90179-R.

[16] Feng,H., L. An., L. Tan., Z. Ho., X. Wang., 2000. Effects of enhanced Ultra violate-B radiation on pollen germination and tube growth of 19 Taxa in Vitro. Environmental and Experimental Botany, 43, 45-53 http://dx.doi.org/10.1016/S0098-8472(99)00042-8.

[17] Gajghate, D.G. and M.Z. Hassan. 1999. Ambient lead levels in urban areas. Bull. Environmental Contamination and Toxicology 62 , 403-408. http://dx.doi.org/10.1007/s001289900889.
[18] Gangloff, D. and G. Moll.1987. In the United States. Unaslyva, 39 , 36-45

[19] Gostin I.N.2009. Air pollution effects on the leaf structure of some Fabaceae species. Not. Bot. Hort. Agrobot. Cluj, 37, 57-63.)

[20] Gratani, L., M.F. Crescente and M. Petruzzi.2000. Relationship between leaf life - span and photosynthetic activity of Quercus ilex in polluted urban areas (Rome). Environmental Pollution, 110, 19-28. http://dx.doi.org/10.1016/S0269-7491(99)00285-7.

[21] Gravano, E., Gilnlietti, V., Desotgiu, R., Bussotti, F., Grossoni, P., Gerosa, G \& Tani, C. (2003). Foliar response of an Ailanthus altissima clone in two sites with different levels of ozone-pollution. En$\begin{array}{llll}\text { vironmental } & \text { Pollution } & 121 & \text { (1), }\end{array}$ http://dx.doi.org/10.1016/S0269-7491(02)00180-X.

[22] Grodzinka, K. 1977. Acidity of tree bark as a bioindicator of forest pollution in southern Poland. Water, Air, Soil Pollution, 8, 3 - 7

[23] Gupta, M.C and A.K.M. Ghouse.1988. Effects of coal smoke pollutants from different sources in the growth, chlorophyll content, stem anatomy and cuticular traits of Euphorbia hirta L. Environmental Pollution 47, 221-230. http://dx.doi.org/10.1016/02697491(87)90212-0.

[24] Hampp, R and W. Ho“11.1974. Radial and axial gradient of lead concentration in bark and xylem of hardwoods. Arch Environ Contam Toxicol, 2, 143 - 51. http://dx.doi.org/10.1007/BF01975468.

[25] Inamdar, J.A. and G.S. Chaudhari.1984. Effect of environmental pollutants on leaf epidermis and leaf architecture of Peristrophe bicalyculata. Journal of plant Anatomy and Morphology 1, 1-8.

[26] Iqbal, M.Z.1985. Cuticular and anatomical studies of white clover leaves from clean and air-polluted areas. Pollution Research 4, 5961

[27] Jarvis, P. G and I.A. Mansfield. 1981. Stomatal Physiology. Cambridge University Press, London.

[28] Kabir,M., M. ZafarIqbal and M. Shafiq. 2012. Traffic dansity, Climatic conditions and seasonal growth of Samanea Saman ( Jacq) Merr. On different polluted roads of Karachi area. Pakistan Journal of Botany, 44(6), 1881-1890

[29] Karandinos, H.G., G.K. Papakostidis and A.A. Fantinnou.1985. In: Lekkas TD, editor. Heavy metals in the environment. International Conference, Athens. Edinburgh: CEP-Consultants, 602 - 6 .

[30] KOVÁCS, M.1992. Trees as biological indicators. - In: Kovacs M. (Ed.) Biological indicators in environmental protection. New York, Ellis Harwood, 207.

[31] Kulshreshtha, K., K. Srivastava and K.J. Ahmad.1994. Effect of automobile exhaust pollution on leaf surface structure of cuticular and epidermal features of Lantana camara Linn. And Syzygium cumini Linn. (Skeels). Journal of Environmental Science.

[32] Kumar, P. and S. Bhathacharya.1999. Down to Earth. 7, 32-40.

[33] Li, M.H.2003. Peroxidase and superoxide dismutase activities in fig leaves in response to ambient air pollution in a subtropical city. Arch Environ Contam Toxicol, 45, 168-176. http://dx.doi.org/10.1007/s00244-003-0154-x.

[34] Mage, D., G. Ozolins., Y. Peterson., A. Webster., R. Orthofer., R. Vandeweerd and Gwyane, R.1996. Urban Air Pollution in Mega City of the World. Atmospheric Environment, 30, 681-686. http://dx.doi.org/10.1016/1352-2310(95)00219-7.

[35] Malhotra, S.S and D. Hocking.1976. Biochemical and cytological effects of sulphur dioxide on plant metabolism. New Phytol. 76, 227-237. http://dx.doi.org/10.1111/j.1469-8137.1976.tb01456.x.

[36] Mandre, M.2002. Relationships between lignin and nutrients in Picea abies L. under alkaline air pollution. Water Air Soil Polution, 133, 361-377.

[37] Mandre, M., J. Klõŝeiko., K. Ots and L. Tuulmets.1999. Changes in photomaas and nutrient partitioning in young conifers in extreme alkaline growth conditions. Environ. Pollution, 105, 209-220.

[38] Mayer, H.1999. Air Pollution in Cities. Atmospheric Environment, 33, 4029-4037.

[39] Meidner, H and L.A. Mansfield.1968. Physiology of Stomata" McGraw-Hill, London, Ting, L. P. (1985) Crassulacean acid metabolism. Annu .Rev .Plant Physiol, 36, 595-622. http://dx.doi.org/10.1146/annurev.pp.36.060185.003115.

[40] Momani, K., A. Jiries and Q. Jaradat.2000. Atmospheric deposition of $\mathrm{Pb}, \mathrm{Zn}, \mathrm{Cu}$ and $\mathrm{Cd}$ in Amman, Jordan. Turk Journal of Chemistry, 24, $231-7$.

[41] Nabais, C., H. Freitas and J. Hagemeyer.1999. Dendroanalysis: a tool for biomonitoring environmental pollution? Sci. Total Environ, 232 (2), 33-37

[42] Nergiz, C and Y. Engez.2000. Compositional variation of olive fruit during ripening. Food Chemistry, 69, 55-59.

[43] Novak, K., J. Skelly., M. Schaub., V. Kraeuchi., C. Hug., W. Landlot and P. Bleuler.2003. Ozone air pollution and foliar injury on native plants of Switzerland. Environmental Pollution 125 (1), 41-52. 
[44] Odukoya, O.O., T.A Arowolo and O. Bamgbose.2000. Pb, Zn, and $\mathrm{Cu}$ levels in tree barks as indicator of atmospheric pollution. Environ Int, 26, $11-6$.

[45] Oliva S.R and B. Valdés.2003. Metal concentrations in Seville orange (Citrus aurantium) fruits from Seville (Spain) and Palermo (Italy). Ann. Bot. Fenn. 40(5), 339-344.

[46] Oliva S.R., B. Valdés and M. D. Mingorance.2008. Evaluation of some pollutant levels in bitter orange trees: Implications for human health. Food Chem. Toxicol. 46, 65-72.

[47] Pacheco, A.M.G., M.C. Freitas, L.I.C., R. Baros and Figueria.2001 Investigating tree bark as an air pollution biomonitor by means of neutron activation analysis. Journal of Radioanalytical and Nuclear Chemistry, 249 (2), 327-331.

[48] Pal, A., K. Kulshreshtha., K.J. Ahmad and H.M. Behl.2002. Do leaf surface characters play a role in plant resistance to auto-exhaust pollution? Flora, 197, 47-55.

[49] Palaniswamy, M., T. Gunamani and K. Swaminathan.1995. Effect of air pollution caused by automobile exhaust gasses on crop plants. Proc. Acad. Environ biol, 4, 225-260.

[50] PETROVA S.2011. Biomonitoring study of air pollution with Betula pendula Roth, Plovdiv, Bulgaria. Ecologia Balkanica, 3(1), 1-10.

[51] Prajapati, S. K., S.K. Pandey and B.D. Tripathi.2006. Monitoring of vehicles derived particulates using magnetic properties of leaves. Environmental Monitoring and Assessment, 120(1-3), 169-175

[52] Prajpati, S.K.2012. Biomontoring and speciation of roadside for heavy metals using Calotropis procera AND Delbergia sissoo. Environmental Skeptics and Critics, 1(4), 61-64

[53] Rai, A., K. Kulshreshtha, P.K. Srivastava, and C.S. Mohanty.2009. Leaf surface structure alterations due to particulate pollution in some common plants. Environmentalist, 30, 18-23.

[54] Rosen, P.M., R.C. Musselman and W.J. Kender1978. Relationship of stomatal resistance to sulfur dioxide and ozone injury in grapevines. Sci Hortic, 8, 137-142.

[55] Sahan Y. and F. Basoglu.2009. Heavy metal pollution in olives grown in Bursa, Turkey. Asian Journal of chemistry, 21, 3023 3029 .

[56] Saralabai, V.C. and M. Vivekanandan.1995. Effect of application of cement exhaust on germination and seedling growth of legumes. Indian J. Pl. Physiol., 3, 257-259.

[57] Sawdis, T., M.K. Chettri., A. Papaioannou., G. Zachariadis and J. Stratis.2001. A study of metal distribution from lignite fuels using trees as biological monitors, Ecotoxicology and Environmental Safety, 48, 27-35.

[58] Scerbo R., L. Possenti., L. Lampugnani., T. Ristori., R. Barale and C. Barghigiani.2002. Lichen (Xanthoria parietina) biomonitoring of trace element contamination and air quality assessment in Livorno province (Tuscany, Italy). Sci Total Environ, 286 (1 - 3), 27 - 40

[59] Semiprocessed vegetables by dehydration. Industria Conserve 61(2), 147-151.

[60] Shah,N.A., M. Afzal and A. H. Bajoi. 2000. Effect of Drought on the performance of Major Fruits in Highland Balochistan, AERU staff paper, 2, 2001

[61] Sharma, M and A.N. Roy.1995. Effect of automobile exhaust on the leaf epidermal features of Azadirachta indica and Dalbergia sissoo. Int. Journal of Mendel, 12 (1-4), 18-19.

[62] Singh, N., M. Yunus., K. Srivastava., S.N. Singh., V. Pandey., J. Misra and K. J. Ahmad. 1995. Monitiring of auto exhaust pollution by road side plants. Environmental Monitoring and Assessment, 34, 13-25.

[63] Trivedi, M.L. and R.S. Singh.1990. Effect of air pollution on epidermal structures of Croton bonplandianum Baill. New Botanist, 17 (3-4), 225-229.

[64] Turunen, M., Huttunen, S., 1990. A review of the response of epicuticular wax of conifer needles to air pollution. Journal of Environmental Quality, 19, 35-45.

[65] Ward N.I., R.R. Brooks and R.D. Reeves.1974. Effect of lead from motor vehicle exhausts on trees along a major through fare in Palmerston North, New Zealand. Environ Pollution, 6, 149 - 58

[66] Wasim, M.R.2011. Trends, growth and variability of major fruit crops in Balochistan, Pakistan: 1989-2009. ARPN Journal of Agricultural and Biological Science, 6, 27-36.

[67] Weyers, J. D B and H. Meidner.1990. Methods of Stomatal Research. Longman, Scientific \& Technical, UK. 